\title{
Three Approaches to Cooperative Learning in Higher Education *
}

\section{DAVID KAUFMAN, ELLIOTT SUTOW, \& KEN DUNN}

Dalhousie University

\begin{abstract}
This paper first discusses cooperative learning and provides a rationale for its use in higher education. From the literature, six elements are identified that are considered essential to the success of cooperative learning: positive interdependence, face-to-face verbal interaction, individual accountability, social skills, group processing, and appropriate grouping. Three distinct approaches at the postsecondary level are described in the fields of Medicine, Dentistry and Mathematics, and feedback from faculty and students is reported. The three approaches are presented within the context of the disciplines and are compared across the disciplines with respect to the essential six elements. Finally, the authors share some lessons learned from their research and experience in order to assist faculty who wish to incorporate cooperative learning into their teaching.
\end{abstract}

\section{Résumé}

Les auteurs de cet article examinent le concept d'apprentissage coopératif et proposent une justification de son application au niveau de l'enseignement supérieur. Les éléments considérés, essentiels à la réussite

* This article is dedicated to the late Ken Dunn, our friend and colleague. Ken gave freely and joyfully of his time and expertise to everyone who came in contact with him. His special contribution to cooperative learning will be missed. 
de l'apprentissage coopératif, proviennent d'articles et d'ouvrages précédemment publiés. Ils sont les suivants: interdépendance positive, intéraction sous forme de face á face verbal, notion de responsabilité individuelle, souabilité, discussions sur le fonctionnement du groupe et regroupements appropriés. Trois approches spécifiques aux domaines de la médecine, la médecine dentaire et des mathématiques y sont décrites ainsi que les observations des professeurs et des étudiants. Les trois approches sont comparées selon les six critères de réussite, déterminés auparavant pour montrer que la nature structurée de l'apprentissage coopératif offre néanmoins un grand champ de manoeuvre. En conclusion, les auteurs de l'article expliquent quelles leçons ils ont tirées de leur recherche et de leur expérience, afin d'aider les professeurs désireux d'introduire l'apprentissage coopératif dans leur enseignement.

\section{Introduction}

Collaborative learning is a spectrum of instruction that involves small groups of students who have been assigned an academic goal. At one end of the spectrum are transient groups that may be formed to quickly generate some ideas for immediate in-class discussion (e.g., "buzz" groups). Cooperative learning is at the other end of the collaborative learning spectrum, since it is a carefully planned learning strategy that involves forming appropriate, sustained learning groups of interdependent members who have been assigned a specific learning goal. Emphasis is placed on student involvement in active learning and the development of social skills. Since the outcomes of cooperative learning are strongly dependent on detailed planning and implementation, cooperative learning has become the most operationally well-defined and procedurally structured form of collaborative learning (Cuseo, 1992). Additional elements of cooperative learning that distinguish it from other collaborative learning techniques are face-to-face verbal interaction, individual accountability, group processing and appropriate grouping.

The above six elements are considered essential to successful cooperative learning. Positive-interdependence requires that "Students have to believe, and act, as if they are in it together, and must care about each other's learning" (Johnson \& Johnson, 1984). Sustained learning groups and reward structures are used to encourage this. Short lived "buzz groups," for example, can be effective for some collaborative learning strategies, but are unlikely to produce the positive-interdependence 
essential to cooperative learning (Johnson, Johnson \& Smith, 1991a, 1991b). Millis (1991) supports this view, noting that group work will better prepare students for the workforce by developing skills in teamwork within diverse groups. Social skills are promoted and enhanced in the task oriented group environment, since students must exercise their leadership, communication, trust-building and conflict resolution skills so they can function efficiently and effectively. A high degree of face-toface verbal interaction is needed so that students are active in the learning process by explaining, arguing, elaborating and linking the new learning material to previously learned facts and concepts (Schmidt, 1989). Cooperative learning requires students to take responsibility for their own learning through the use of examinations that demand individual accountability. Even though students help one another, no group member can afford to sit back and "hitchhike." Group processing requires members to periodically assess how well they are working together and how they could improve to ensure successful and efficient completion of their academic tasks, as well as score high in tests. Lastly, appropriate grouping by the teacher ensures that each group contains members with various attributes to strengthen problem-solving and social skill building of all group members.

One of the "Seven Principles for Good Practice in Undergraduate Education" calls for cooperation among students. Chickering and Gamson (1991) explain this principle as follows:

Learning is enhanced when it is more like a team effort than a solo race. Good learning, like good work, is collaborative and social, not competitive and isolated. Working with others often increases involvement in learning. Sharing one's ideas and responding to others' reactions improves thinking and deepens understanding. (p. 65)

While cooperative learning techniques may be novel to some students in the health science or mathematics classroom, graduates learn early the importance of teamwork in the workplace. Boyer (1990) asserted that if democracy is to be served, cooperation is essential. He argued that cooperation is essential to the academic program, and most especially, to procedures in the classroom. He urged, therefore, that students be asked to participate in collaborative projects, that they work together occasionally on group assignments and that special effort be made, through small seminar units within large lecture sections, to create 
conditions that underscore the point that cooperation is as essential as competition in the classroom.

Cooperative learning as an instructional strategy is most frequently used at the Kindergarten to Grade 12 level where much research has been conducted (Bennett, 1991; Bossert, 1988-89; Johnson, Maruyama, Johnson Nelson \& Skon, 1981; Johnson \& Johnson, 1989; Slavin, Sharan, Kagan, Hertz-Lazarowitz, Webb, \& Schmuck, 1985; Slavin, 1980, 1983, 1990; Stevens, Madden, Slavin \& Farnish, 1987).

Most research on the various cooperative learning techniques has been conducted in field experiments, in which the cooperative learning classes were compared to control classes, and often to classes using modifications or components of the techniques. Slavin's reviews $(1980,1983)$ were restricted to field studies in which: 1) practical techniques were used by teachers in classrooms for at least two weeks; 2) appropriate control groups were used; and 3 ) individuals were tested after the group experience. Outcome measures included variables such as academic achievement, intergroup (or race) relations, self-esteem, mutual concern among students, attitudes toward school, and ability to work cooperatively.

Johnston, et al. (1981) used three formal meta-analysis procedures in their review: the voting method, the effect-size method, and the z-score method. They reviewed 122 studies conducted in North America that contained achievement or performance data, and compared two or more of the four goal structures: cooperation, cooperation with intergroup competition, interpersonal competition, and individualistic effort. Results of the several reviews and meta-analyses support the contention that the use of cooperative learning methods results in improvements both in student achievement and in the quality of their interpersonal relationships.

While it is much less practiced and researched at the university level (Basili \& Sanford, 1991; Dansereau, 1988; George, 1994), cooperative learning is being used in professional education (Cinelli, Symons, Bechtel \& Rose-Colley, 1994; Glendon \& Ulrich, 1992). Two highly compelling endorsements of cooperative learning in higher education have been provided by Astin (1993) and Terenzini and Pascarella (1994). Astin studied 22 outcomes and 88 environmental factors in 159 degree-granting institutions. He reported that student-student interaction and student-faculty interaction were the most powerful factors and affected the largest number of general education outcomes. Astin concluded that how students approach their education and how faculty deliver the curriculum is far 
more important than the formal curriculum content and structure. These findings led Astin to strongly endorse collaborative learning techniques as being more potent than traditional methods of teaching. The work of Terenzini and Pascarella (1994) lends additional support to the use of cooperative learning at the university level. The authors reviewed, from the last two decades, 2,600 books, book chapters, monographs, journal articles, technical reports, conferences, papers and research reports on student learning. They explained that individualized and collaborative approaches to instruction are more effective than traditional (lecture) approaches because they respond better to differences in students' levels of preparation, learning styles and rates. Terenzini and Pascarella concluded, "The research literature indicates active learning produces greater gains in academic content and skills; it clearly supports efforts to employ various forms of collaborative learning" (p. 30).

In the highly structured cooperative learning classroom, daily activities are operationalized from specific plans, which are content-free procedures (Kagan, 1990; Millis, 1995). These structures have been described elsewhere and have been given labels such as think-pair-share, three-step interview, roundtable, structured problem-solving, jigsaw, send/pass-a-problem and dyadic essay confrontation. When content is added to these structures they become specific classroom activities. However, structure alone is not enough to ensure success; faculty need to learn classroom management techniques (Millis, 1995). Davidson and Worsham (1992) outline eleven teacher roles in cooperative learning: instructor, facilitator, moderator, expert resource, manager, curriculum specialist/planner, observer, processor, model, coach and evaluator. Implementing cooperative learning in the classroom is more complex and demanding for the teacher, as well as the student. Faculty development is essential to assist faculty in the role transition from traditional teaching methodologies.

This paper describes three distinct approaches to the use of cooperative learning in the undergraduate curricula in Medicine, Dentistry and Mathematics. The three approaches are presented within the context of the disciplines and are compared across the disciplines with respect to the six essential elements, which were identified earlier. Lessons learned from the planning, implementation and evaluation of these efforts are presented to assist faculty who wish to incorporate cooperative learning into their teaching. The paper shows that the highly structured nature of 
cooperative learning still offers a large degree of flexibility to accommodate the diverse needs of postsecondary disciplines and allows students and faculty to interact in a creative and supportive environment.

\section{Examples of Three Cooperative Learning Programs}

\section{An Undergraduate Medical Curriculum}

Description. In September, 1992, our medical school welcomed a class of 84 students to its new problem-based learning (PBL) curriculum (Mann \& Kaufman, 1995a). PBL is a method of teaching around case problems in which learning results from the process of working towards the understanding or resolution of a problem (Barrows \& Tamblyn, 1980). The literature on PBL describes this technique as a small-group problem-solving activity involving cooperation among members of the group, and utilizing the six elements described earlier. The psychological basis for PBL is consistent with the one given for cooperative learning (Norman \& Schmidt, 1992; Schmidt, 1989). The three learning theory principles which apply are: activation of prior knowledge, learning in context, and elaboration of knowledge. PBL addresses the requirements of professional practice, such as teamwork and communication skills (Kaufman, 1995). Since no member of the group has enough knowledge to completely resolve and explain the problem being discussed, students must cooperate with one another. The group becomes a kind of integrated learning team.

The first two years of the four-year medical curriculum are devoted largely to learning the basic sciences required in clinical practice. Students proceed sequentially through a series of science courses (called "units"), in which they are randomly assigned to small groups of 7-8 students with a faculty tutor. The groups are changed each 8-10 weeks.

Students meet three times per week for two-hour tutorials. In the first year, the faculty tutor is always present; in the second year, the tutor is required to attend only two of the three weekly tutorials. Students work through one case each week, using a structured clinical reasoning process (Kaufman, 1995). Each case consists of several pages (typically 4-8 pages), and unfolds through a patient presentation, history, physical examination and laboratory findings. During the tutorials, students identify learning issues, which are recorded on a flipchart at the end of each session. These learning issues are assigned either to the 
whole group, teams of students or individuals, who engage in selfdirected study outside of the tutorial session. Students then report their findings to their group members at the next session. The effective functioning of the group depends on the contributions of individuals, as well as on the degree of cooperation within the group.

The tutor performs several functions in the group (Barrows, 1988; Kaufman, 1995). The first function is 'navigating,' which requires the tutor to assist the group to work through (navigate) the steps of the learning process. The second is 'questioning,' which refers to the tutor's posing of questions, both cognitive and metacognitive (e.g., "Can you explain your reasoning?"). The third function is 'facilitating,' which refers to the actions taken by the tutor to create and maintain a positive and productive group process. Finally, the tutor is continually monitoring the educational progress of each student in the group ("diagnosing"). A tutor who notices early that certain students are having difficulties can assist these students before it is too late. These difficulties can take many forms, such as poor participation in discussions, faulty reasoning, poor knowledge base, and inability to locate appropriate information. Barrows (1988) has explained how the tutor evolves through three roles, referred to as modeling, coaching and fading. The aim is for students to assure increasing responsibility for their own learning, with the tutor serving as a "safety net" for the group.

\section{Preparing Faculty and Students}

Faculty Development. A controversial issue in PBL is whether the tutor needs to be a content expert. The literature suggests that the ideal tutor is one who is a content-expert as well as an expert in the studentcentred tutorial process (Kaufman, 1995). However, if tutors are not subject matter experts, their students can achieve a level of performance equal to students tutored by subject matter experts, as long as the nonexpert tutor is properly prepared for the case. In our medical school curriculum, the majority of faculty are non-expert in many of the cases. This is essentially a practical issue, since there are not enough experts in each content area for all eleven tutorial groups.

Therefore, faculty development is an essential activity for tutors, and has been described in detail elsewhere (Holmes \& Kaufman, 1994; Kaufman, 1995). More than 250 faculty have attended our day-and-a-half tutor training workshop, in which practice is provided using "simulated" 
students who have been hired for the day. This is followed by a unit orientation meeting, weekly tutor meetings after each case, peer observation of new tutors, and a formal tutor evaluation by students. Finally, advanced skill building workshops are held as needed.

Preparing Students. Since students will spend the first two years of their medical school curriculum learning the basic sciences, mostly in small group tutorials, some preparation is essential. Therefore, the first week of medical school is an "Orientation Week," which combines faculty and student organized activities. During this week, faculty describe the curriculum and explain the rationale for problem-based learning. Second year students do a demonstration of a "good" and "bad" group, and offer "tips" for effective tutorial groups. First year students then practice with a short case, in two tutorial sessions, and later attend a debriefing session with faculty and staff.

Evaluation of Students. Students are evaluated on both the process and outcomes of their learning. They must achieve a "pass" grade in both their tutorial evaluation (by the tutor), and the end-of-unit examination. A tutorial evaluation form is completed by the tutor, and discussed with each student. The areas assessed are: use of reasoning process, acquisition, integration and application of knowledge, communication skills, interpersonal skills, and self-assessment. The three hour end-ofunit examination typically includes a mini-case, with short answer questions. By policy, no multiple choice questions are permitted.

Feedback from Students and Faculty. Students have been strong supporters of the new PBL curriculum, and their feedback has been very positive. Results from a comparative study of the PBL students with the

- previous conventional curriculum students have been reported elsewhere (Kaufman \& Mann, 1996a, 1996b; Mann \& Kaufman, 1995b). Students' perceptions of their courses were compared across the two curricula with regard to important features of cooperative learning. Table 1 presents some findings, which are statistically significant $(p<.001)$ in favour of the PBL group on all features.

Students were interviewed in depth during their first year about the small-group tutorial process, and the following conclusions were reached:

1. Most learning/studying is done outside the formal group, either alone or in student-organized groups. However, a well-functioning group allows more learning to be done in the group than a poorly functioning one. 
Table 1

Comparison of Student Perceptions About Courses (PBL vs. Conventional)*

\begin{tabular}{|c|c|c|c|}
\hline Feature & $\begin{array}{c}\text { PBL } \\
(n=72)\end{array}$ & $\begin{array}{l}\text { Conventional } \\
\qquad(\mathrm{n}=73)\end{array}$ & \\
\hline & Mean (sd) & Mean (sd) & t-value $* *$ \\
\hline 1. Learning details & $5.22(1.64)$ & $7.47(1.27)$ & 9.25 \\
\hline \multicolumn{4}{|l|}{ 2. Understanding principles } \\
\hline and being able to use them & $7.66(1.29)$ & $5.90(1.96)$ & 6.36 \\
\hline \multicolumn{4}{|l|}{ 3. Integrating different subjects } \\
\hline 4. Articulating previous knowledge & $7.01(1.23)$ & $5.63(1.66)$ & 5.72 \\
\hline 5. Stating learning objectives & $6.64(2.12)$ & $5.04(2.18)$ & 4.49 \\
\hline 6. Making decisions & $6.12(1.62)$ & $4.90(1.93)$ & 4.13 \\
\hline 7. Independent thinking & $7.16(1.29)$ & $4.83(1.92)$ & 8.56 \\
\hline 8. Problem solving & $7.73(1.07)$ & $5.40(1.72)$ & 9.73 \\
\hline $\begin{array}{l}\text { 9. Gathering and analyzing } \\
\text { information }\end{array}$ & $7.60(1.13)$ & $5.25(1.84)$ & 9.28 \\
\hline 10. Stimulating and enjoyable & $7.18(1.45)$ & $5.42(2.19)$ & 5.70 \\
\hline 11. Stimulated to learn more & $7.36(1.34)$ & $5.58(2.12)$ & 6.02 \\
\hline $\begin{array}{l}\text { 12. Stimulated to read medical } \\
\text { literature }\end{array}$ & $6.88(1.92)$ & $4.38(2.58)$ & 6.62 \\
\hline \multicolumn{4}{|c|}{$\begin{array}{l}\text { *To what extent were your courses characterized by the following features } \\
(1=\text { small extent, } 9=\text { =large extent }) ?\end{array}$} \\
\hline
\end{tabular}


This was the best group I had. It was excellent, dynamic, and I guess it was because everyone was relatively serious, focussed and we got a lot done in a very short period of time. It just seemed to be one of the most efficient groups, it had great flow; it wasn't as though there was any abrasion.

2. Both personality mix and degree of commitment/effort affect group function, but degree of effort on the part of members has more effect.

They're all hard-working, so that makes me work harder, especially at this time of year. If I was in a group where things were laid back, I would definitely be laid back, and maybe not contribute as much as I should.

3. Tutor behaviour has a profound effect on the function of a group.

We had a tutor who was very dominant, made up our learning issues, and decided which order people would present them in. He would interrupt people as they were doing their learning issues, and a lot of times finish them, and he spent an equal amount of time talking, as all of us put together, during the tutorials. And when he left and our new tutor took over, our group got better ... the group grew, it sort of blossomed.

Feedback From Faculty. Faculty were positive about their experience, and were satisfied with students' learning, group dynamics, interest, and enthusiasm. They rated students' learning, group dynamics, and students' interest and enthusiasm highly $(4.12,4.11$ and 4.38 on a 5 -point Likert scale). However, room for improvement was noted in tutors' self-rating of their role and overall performance, and they rated their overall performance as a tutor lower (3.62). Some faculty comments after their first tutoring experience were:

The most enjoyable aspect was seeing students come in at a 'nothing' clinical level, and in a short time, they were synthesizing knowledge and coming up with reasonable clinical explanations.

I was skeptical at the start, and wasn't sure how the process would work; I am a convert now. The process should produce good physicians. 


\section{An Undergraduate Dental Course}

Description. Cooperative learning was used in a basic science course, "Dental Biomaterials Science," in the second year of the curriculum. The course is designed to help students build their knowledge base and develop their critical thinking skills relative to the application of biomaterials science in Dentistry. Specifically, students are expected to acquire the knowledge base and understand the relevant basic science concepts, and be able to apply them critically for the selection, manipulation, insertion and long-term observation of clinical materials. Additionally, students are expected to interpret and apply the results of laboratory and clinical research studies to the resolution of clinical problems. Manual skill-building is not part of this course, although students would have had some hands-on exposure to dental biomaterials in the first year of the curriculum and would have additional exposure to the clinical use of materials during their second year, while the Biomaterials Science Course is in progress.

The major planning thrust in using cooperative learning in this basic science course was to change a traditionally teacher-centered lecturebased course to a student-centered, group work environment that would require students to be active in the learning process and to develop their interpersonal skills. Group work focused on activities that involved acquiring the knowledge base and problem-solving. Some cooperative learning structures were more competition- and fun-oriented, and used modifications of Teams-Games-Tournament Technique and Cooperative Group Investigation Technique, especially when acquisition of the knowledge base was emphasized (Slavin, 1980). Each week of this fullyear course consisted of a one hour class (on Friday) devoted to lectures, and a two hour class (on Wednesday) devoted to cooperative learning. Friday lectures introduced the knowledge base of a new subject area, while Wednesday classes were used mainly for cooperative learning. This placed the major emphasis on higher-order cognitive skill development in class (i.e., two-thirds of the course time), but also satisfied student desire for direction from faculty. Lectures helped students understand the information in dental biomaterials science textbooks, related engineering textbooks and the dental literature, which is often beyond the academic entrance requirements for dental school. Lectures also addressed the need to update the textbook in the rapidly evolving applied science of advanced dental biomaterials. 
Group work assignments were designed to use the first 30-60 minutes of the cooperative learning class time, followed by presentation of the results to the entire class and faculty. Presentations represented group accountability, since classmates and faculty were expected to critique what they heard. Homework assignments, which were actually takehome examinations, represented individual accountability. The final course grade was based solely on homework assignment grades. Students were randomly assigned to their groups of four or five students. New groups were formed about every eight weeks during the academic year, giving each student experience with four different groups.

The proper sequencing of homework and class activities was believed critical to the success of group work. It was imperative that students come to a cooperative learning session only after having studied the assigned biomaterials science knowledge base and concepts. Rather than using in-class quizzes to require student preparation for class, the written homework assignments (generally 500-750 words) served this purpose. This form of take-home examination permitted the use of problem-solving questions that required higher-order thinking. Homework was due on the appropriate cooperative learning day. The lecture that preceded a particular cooperative learning activity was designed to help students set learning priorities and sift through a generally new and large knowledge base. On a few occasions, preparation for the cooperative learning day was preceded by a laboratory exercise on the subject. In summary, the sequence was: 1) homework assigned 2) lecture 3) laboratory exercise, and 4) homework due/cooperative learning activity. Laboratory exercises were an extension of the lecture classes and not intended to build manual skills.

There was a major emphasis on providing variety and clinical application in the cooperative learning activities. Many of the activities that required problem-solving and group or individual presentation of the solution were a modification of the standard techniques of Think-PairShare or Jigsaw (Millis, 1995). Each of the eight groups was assigned a different problem. Problems were generally patient-centered and required students to apply the knowledge base and concepts to situations that often had no single or simple answer. Faculty acted as a resource and circulated among the groups. They were instructed to avoid minilectures when interacting with a group, but to offer information and direction depending on the degree of difficulty of the problem and the 
prior knowledge of the students. Presentation of a group's results to students and faculty served as a type of group accountability, since listeners were free to critique what they heard. Groups followed the rule that being a presenter was to rotate weekly among group members. Overhead materials were supplied to each group to assist the presentations. Groups mostly worked independently of faculty. This was believed to have resulted from the level of preparation fostered by the homework assignments and a personal desire to be active in the learning process.

\section{Preparing Faculty and Students}

Faculty Development. The use of problem-based learning in a course that tries to bridge the gap between a basic science course and its clinical application requires that faculty ideally be subject matter experts in all components of both areas. This unlikely occurrence was addressed by having an experienced clinician, in addition to the three basic scientists, as one member of the faculty team. The introduction of cooperative learning was spearheaded by the course director who had attended two workshops on cooperative learning and had studied the appropriate literature. The use of cooperative learning was discussed at department meetings and all teaching faculty were supportive of trying this method, even though it was not being used in any other course in the dental curriculum. All departmental teaching faculty were philosophically in agreement with the teaching methodology of cooperative learning and were prepared to let the course director lead them. The course director described to his colleagues the basic elements of cooperative learning, its educational foundations and the delivery strategy that was planned for the Dental Biomaterials Science course. In the first term, the course director was responsible for writing most of the cooperative learning activities, while the other instructors acted as resources. The course director also assisted faculty in developing their own problem-based cooperative learning activities for their sessions.

Preparation of Students. Cooperative learning was started in the first class of the course. Students were given a handout that included a course description and syllabus. The course director used 15 minutes to present an overview of cooperative learning and describe the student and faculty roles. Students were then assigned to their groups and given an in-class assignment. The objective was to design their own Dental Biomaterials Science course syllabus based upon actual commercial 
dental technical literature that appears in dental journals or is mailed to a practitioner's office. Students were told to use their experience with dental biomaterials gained from their first year dentistry courses and any other prior knowledge. Groups were also expected to defend their syllabus. During this group work, faculty circulated from group to group, acting as a resource.

Evaluation of Students. Students were evaluated individually using essay-type take-home examinations that were problem-based (homework assignments). They were encouraged to work in groups to research and discuss homework, but were required to work individually when actually writing their assignments. This expression of faith in student integrity was also intended to demonstrate to students that faculty believe that cooperative learning is not just an academic exercise for the classroom. All homework assignments were open-book, since rote memorization was de-emphasized in the course. In-class group work was assessed, but not graded, when a group representative (or representatives) presented the results of the cooperative learning activity to students and faculty. Listeners were free to critique the information and analysis presented. Presenters and their group colleagues could accept the corrections and comments offered by the listeners or rebut them. This form of evaluation was approached seriously by students, as shown by the high quality of the presentations.

Feedback from Students and Faculty. It was the responsibility of the course director to ensure that the course was conducted effectively and that faculty were prepared with relevant and challenging cooperative learning assignments. Immediately after each cooperative learning session, the course director assembled the faculty present to critique the session. This timely evaluation and feedback was extremely useful, especially for preparation of the next session. Faculty participated enthusiastically in these debriefing activities, which demonstrated their commitment to improving the process.

During the last class of the first term, students were asked to complete a course questionnaire that was designed, in part, to assess student response to cooperative learning. Thirty-one of 33 students completed the questionnaire, for a response rate of $94 \%$. Forty-five percent of the respondents reported that this course was their first experience with cooperative learning. Lack of experience with cooperative learning for this group may be due, in part, to the competitive and individualistic 
learning models that are used commonly in university science courses, which are prerequisites for entrance to dental school.

The majority of students (68\%) indicated that they were enjoying cooperative learning ("I feel this is an excellent way to learn."), while only one student indicated he/she was not enjoying the method ("I don't particularly enjoy it. I think this is because of my own personal style of learning."). The majority opinion confirmed the faculty's impressions throughout the term that students were generally positive about cooperative learning, as indicated by their high level of communication within their groups. A summary of the results is presented in Table 2.

Students revealed that they prefer the student-centered, active learning of cooperative learning. Many comments contained criticisms of past experiences with lecture-dominated courses: "more interesting than just

Table 2

Perceptions of Case-Based Dentistry Students $(n=29)$

\begin{tabular}{lccc}
\hline $\begin{array}{l}\text { Question } \\
\text { Yes }\end{array}$ & $\begin{array}{c}\text { Percent (\%) } \\
\text { No }\end{array}$ & Undecided \\
\hline $\begin{array}{l}\text { Are you enjoying the cooperative } \\
\text { learning method? }\end{array}$ & 68 & 3 & 29 \\
$\begin{array}{l}\text { Has the use of cooperative learning } \\
\text { helped you to enhance communications } \\
\text { skills, improve interpersonal skills and } \\
\text { reduce competition? }\end{array}$ & 58 & 29 & 13 \\
$\begin{array}{l}\text { Has the use of cooperative learning } \\
\text { helped you to be more active in the } \\
\text { learning process and helped to promote } \\
\text { critical thinking in comparison with } \\
\text { lectures, for example? }\end{array}$ & & & \\
$\begin{array}{l}\text { Has cooperative learning been a good } \\
\text { method for promoting understanding } \\
\text { and retention of Biomaterials Science? }\end{array}$ & 84 & 64 & 10 \\
$\begin{array}{l}\text { Did you find group work appropriate to } \\
\text { your learning style? }\end{array}$ & 77 & 6 & 10 \\
\hline
\end{tabular}


sitting down for two hours and taking notes"; "makes classes more interesting and tolerable - much better than learning everything by lecture and memorization." The positive comments about cooperative learning were many and varied, including: "we can draw from the knowledge of a group;" "drives the students to learn their material so that they don't look ignorant in front of their peers;" "allows students to associate with each other on an academic level;" "helps to develop a sense of cohesiveness between class members:" "you have the chance to talk with classmates to come up with answers and explanations. It's not just fed to you,"; "it helps us communicate more effectively and more often."

Faculty were pleased that students were enjoying the cooperative learning method, as indicated in the course questionnaire. They shared the student perception that cooperative learning was a good alternative to a lecture-based course. However, one faculty stated he would like to offer more guidance to the groups to ensure the students were learning the course material correctly, especially when particular subjects were not covered in the lecture portion of the course. On the other hand, faculty welcomed their role as facilitators and the opportunity for targeted comments during the active learning of group work and during student presentations. Most of all, as indicated by the quality of group work, inclass presentations and homework assignments, faculty agreed that cooperative learning engaged students in the learning process and created a much more positive in-class learning environment in comparison to the sole use of lectures.

\section{An Undergraduate Mathematics Course}

Description. In 1988 two members of the Department of Mathematics, Statistics and Computing Science met with a colleague from the School of Education to discuss the introduction of some of the ideas involved with the "calculus reform movement" in the basic first year calculus course at Dalhousie. The mathematicians hoped to implement three important components of calculus reform: 1) a change in emphasis in the content of the course from developing manipulative skills to promoting an understanding of, and ability to use, the concepts of the calculus; 2) the use of technology - calculators and/or computers - as teaching and computational tools; and 3) changes in the teaching approaches used in the classroom.

The major pedagogical innovation was the introduction of cooperative learning techniques to change the thrust in the classroom from exclusively 
lecture-based to a student-centered, group-work environment. The cooperative techniques that were used can be categorized under the general headings of "formalized structures," "formal groups" and "informal groups." The majority of the cooperative learning in our calculus classrooms has been accomplished through formal and informal groups.

Formalized Structures. We used two formalized structures Jigsaw and Clue Cards. Jigsaw has been discussed widely in the literature (Kagan, 1990). Our jigsaws are done over three fifty-minute class periods and we attempt, at most, one jigsaw per academic term.

Clue Cards is a cooperative learning technique that originated in the "Equals" Project at the University of Berkeley in the context of public school education and pre-service teacher education (Cobb \& Conwell, 1988; White \& Conwell, 1988). We have described its use elsewhere in more detail (Crowley \& Dunn, 1994). In a nutshell, a group of four to six students is asked to work on a problem by giving each student a card with a portion of the needed information. Each student must read aloud the clue on his or her card to the others, and then all must collaborate to find the solution. Upon completing the activity, a summary of the solution is produced by the group. We have used clue cards at least once a month in the calculus classroom. We find them particularly useful for reviewing material, considering applications and consolidating ideas.

Formal Groups. By formal groups we simply mean groups that are put together for extended periods of time to carry out various activities together. We usually keep groups together for an academic term. Each group is made up of four students. We prefer to "hand pick" the groups to seek gender balance and a balance of individuals with weak and strong mathematical backgrounds.

Most of the work done by these formal groups is accomplished outside the classroom. About two-thirds of all assignments are done by groups. In addition, we give a major take-home test each term which is done by the groups. Finally, in the second term of the course we have each group work on a project over a period of about two months, culminating in group class presentations. These projects involve open-ended problems which encourage students to use the library, to use the computer as a tool in their problem solving and to talk with each other about the mathematics they have learned and how it can be applied to these "real world" situations. 
Informal Groups. By informal groups we mean groups, usually of two students, which are put together in class for a specific task and then disbanded. This is essentially the technique called Think-Pair-Share (Kagan, 1990). Students first are asked to think about a topic or work on a problem associated with material discussed in class. They then pair up to discuss and come to agreement on the question. Finally, several of the groups share their ideas with the class.

Approximately one-third of the class time involves cooperative learning, with some classes devoted exclusively to cooperative work, some devoted exclusively to lectures and most involving a combination of both. The majority of the time that students spend outside of class on mathematics is in a group situation. In all cases, the purpose is to get students thinking and talking about mathematics.

Preparing Faculty and Students. When we began the project, the mathematicians had very little knowledge about cooperative learning techniques and no experience with the implementation of the techniques in the classroom. Our mathematics education colleague was particularly helpful in this regard. She opened the literature to us, encouraged us to experiment with various techniques and she attended many classes to "critique" what we were doing and also to help with the methods.

We found that it was very helpful to have a small group of colleagues who could discuss the problems and successes that we encountered. Our department was willing to let us try our experiment, but no other members were interested in being involved themselves. In our experience, it would have been very difficult for a person, working on their own, to introduce cooperative learning techniques into their classroom.

We found that the changes in teaching methods called for changes in content as well. The standard calculus problems were no longer appropriate for students working in groups. This led to many hours of discussion between the two mathematicians to put together problems and questions for assignments, tests and projects. Preparing material for a jigsaw and cards for clue cards also involves a great deal of time. Of course, much of this material can be used for several years.

The first day of class involves two cooperative learning activities. We begin by giving our students three Clue Card activities. The first consists of a simple problem which students have fun solving. This allows them to familiarize themselves with the technique without being threatened by the content. The other two activities involve material 
which we consider to be a review of high school mathematics. We complete the class by introducing the students to their formal groups.

Starting the term in this way serves several purposes. One is that the students go away from class, the very first day, knowing at least three other people. Another is that we have set the tone for the rest of the term - students are expected to actively and cooperatively contribute to the learning in the classroom.

Evaluation of Students. Students in formal groups are graded on the assignments, tests and the project. All the work that is done in a formal group setting is graded - with each group member receiving the same grade. We have had very little trouble with individuals not carrying their weight, although we have had situations where a student does not fit with the other members of the group and this has led to some restructuring of groups. This has always occurred early in the term and we have encouraged students to let us know within the first couple of weeks of classes if their group is not working well. In several extreme cases we have simply been forced to let a student work alone. We have tried having students grade each other on their contributions to the group, but this has not proven to be particularly informative. We also have several assignments, and at least one "competency" test, which students do on their own.

Jigsaws, clue cards and the work of the informal groups done in class are not graded. The emphasis in these techniques is to get students thinking about, talking about and doing mathematics rather than producing a product that can be graded. We inform students that each member of the group is responsible for understanding what the group has done. From time to time, we reinforce this by calling on a random group member to orally present the group's results. We do not, however, assign a group or individual grade to the work.

Feedback from Faculty and Students. When we began the experiment, our expectation was that the students would focus on, and be most interested in, the introduction of technology. Through class evaluations and also through several exit interviews conducted by the faculty member in Education, we found that, although the students found the computer a useful tool, they were most enthusiastic about the use of cooperative learning techniques in the mathematics classroom. They like having the chance to talk about mathematics with each other both inside and outside of the classroom. It gives them the opportunity to clarify their own ideas and misgivings on a topic in a non-threatening environment. This is often 
the first time they have been encouraged to talk about mathematics and they feel that they benefit from hearing how other students think through a problem or explain an approach. Finally, they enjoy the feeling of success - a group of heads is usually better than one.

Jigsaw is perhaps the one technique which has shown mixed results. We have polled our students and the following are two typical reactions.

I found the jigsaw method to be a very worthwhile exercise. I didn't find teaching my group very intimidating and there was plenty of time to get my work done. I would like to see this method used again because it is very helpful.

I did not feel this method for teaching was constructive or worthwhile for this class. It takes a lot of time and organization to get this accomplished. I didn't feel that the material was adequately covered by my classmates.

The two mathematics faculty members have been very encouraged by the introduction of cooperative learning techniques. Classrooms which were beginning to become stale seem to have a new breath of life. Although there is a great deal of work involved in preparing for class, the subject material has renewed interest. The faculty are able to get to know students in a way previously unavailable to them - through watching, listening and questioning them as their groups go through problem-solving processes. Finally, cooperative learning activities are quite self-revealing. Students have realized on their own, from listening to others in their group, that their backgrounds were not adequate and have come to speak to us early in the term. Others, who were unsure about the level of their mathematical skills, have gained in confidence through discussions with their peers.

Bassarear and Davidson (1992) state that the frequent use of cooperative learning methods in mathematics can foster the following benefits for students:

- Opportunities to discuss and clarify concepts, freely exchange ideas, ask questions, give and receive help, explore situations, look for patterns and relationships in sets of data, and formulate and test conjectures.

- Learning varied approaches for solving the same problem.

- Support for problem solving, logical reasoning and making mathematical connections. 
- Learning to communicate in the language of mathematics.

- The chance to learn from "mistakes" in a nonthreatening environment.

- Decreasing math anxiety and increasing math confidence.

- Accommodation of diverse learning styles.

- Making friends with group members across boundaries of race, class and gender.

- Increased ability to cooperate with others and develop social skills.

- A lively, engaging and enjoyable mathematics class.

Our experiences using cooperative learning techniques in the calculus classroom completely support these conclusions.

\section{Comparison of the Three Approaches}

The three approaches described in this paper were developed and delivered independently of each other. In this section, they are compared with regard to the six elements essential to implementing cooperative learning, outlined earlier in this paper. The primary role of the instructor in each approach also is compared. These comparisons support our contention that cooperative learning is a structured approach, which still offers a high degree of flexibility to accommodate the diverse needs of students. An examination of Table 3 shows that the three approaches contain all of the essential elements (to varying degrees and provided in different ways).

All three approaches ensure positive interdependence. The Medicine and Dentistry approaches require that individual students report their learning to their peers; the Mathematics approach relies on the use of formalized structures, e.g., Jigsaw, which requires that each individual contributes for the successful completion of the assigned task. All three programs ensure individual accountability through the use of individual assignments, and individual assessment of student performance.

Verbal, face-to-face interaction is incorporated into each approach. The Medicine and Mathematics approaches impose a structured process for reasoning through a case or solving a problem. The Dentistry course requires that students apply critical thinking skills, but does not impose a specific reasoning process. The Medicine approach requires that the small-group, faculty tutor assesses students' social skills ("interpersonal" 
Table 3

Comparison of Approaches and Elements of Cooperative Learning

Element

Verbal, Face-to-Face

Individual Accountability

Social Skills
Problem-Based Learning in Medicine

Members depend on reports from each other. Group members monitor performance and apply peer pressure when necessary.

Students work through a case using a structured reasoning process.

Students write a final exam. Tutor assesses individual student's tutorial performance.

Emphasized and assessed by tutor.
Case-Based Peer Groups in Dentistry

Groups must report to whole class.

Students use their critical thinking skills. No imposed process.

Inidividual homework assignments are graded.

\footnotetext{
Important but not assessed.
}

Cooperative Learning

Strategies in Mathematics

Formal structures ensure this.

\section{Students use specific}

formalized structures to solve problems.

Individual tests and assignments are graded. Group monitors accountablility of members.

Important but not assessed. 
Table 3 (continued)

\begin{tabular}{|c|c|c|c|}
\hline Element & $\begin{array}{l}\text { Problem-Based Learning } \\
\text { in Medicine }\end{array}$ & $\begin{array}{l}\text { Case-Based Peer Groups } \\
\text { in Dentistry }\end{array}$ & $\begin{array}{l}\text { Cooperative Learning } \\
\text { Strategies in Mathematics }\end{array}$ \\
\hline Group Processing & $\begin{array}{l}\text { Tutor and groups are } \\
\text { encouraged to discuss process }\end{array}$ & $\begin{array}{l}\text { Groups process is discussed } \\
\text { with instructor when necessary. }\end{array}$ & $\begin{array}{l}\text { Group must process to resolve } \\
\text { incompatibility or task will not } \\
\text { be accomplished. }\end{array}$ \\
\hline Appropriate Grouping & $\begin{array}{l}7-8 \text { members, } 8-10 \text { weeks, } \\
\text { random assignment, gender } \\
\text { balance, new members each } \\
\text { time. }\end{array}$ & $\begin{array}{l}4 \text { members, } 8 \text { weeks } \\
\text { random assignment. }\end{array}$ & $\begin{array}{l}2-4 \text { members, formal - } 13 \text { weeks, } \\
\text { informal - as required; } \\
\text { instructor selected, gender } \\
\text { balanced, varying abilities. }\end{array}$ \\
\hline Instructor Role & $\begin{array}{l}\text { Facilitates the group, } \\
\text { questions and evaluates. } \\
\text { Remains with group. }\end{array}$ & $\begin{array}{l}\text { Serves as expert resource. } \\
\text { Floats from group to group. }\end{array}$ & $\begin{array}{l}\text { Serves as expert resource. In } \\
\text { class - floats from group to } \\
\text { group; outside class - } \\
\text { facilitates and provides } \\
\text { information as required. }\end{array}$ \\
\hline
\end{tabular}


and "communication" skills). The two other approaches emphasize social skills, but do not formally assess these.

The Dentistry and Mathematics courses do not explicitly require the small groups to do "group processing," i.e., to discuss periodically how well the group is functioning. The Mathematics course has used formalized structures which have been described extensively in the literature. These structures require effective group functioning in order to successfully solve the problems presented. Although not emphasized explicitly, group processing must occur if a group is not working well; otherwise, the group will be hampered in its ability to complete its tasks. The Medicine PBL faculty tutors and students are encouraged to discuss their group process at the end of each week, or when a problem is perceived in the group. Skilled faculty also are available upon request to observe a group, and to facilitate a discussion on how to improve group processing.

With regard to grouping, the Medicine and Dentistry approaches use random assignment, while the Mathematics course assigns students to ensure heterogeneous groups. Medicine and Mathematics ensure an appropriate gender balance, and all three approaches maintain the formal groups from 8-13 weeks. This allows the groups to develop their cohesiveness and smooth out any "rough edges." The Dentistry and Mathematics courses limit the group size to four members; the Medicine curriculum assigns students to groups of $7-8$ members due to resource constraints.

Finally, the Medicine approach emphasizes the faculty tutor's role as a facilitator of the small group process. Most tutors are not subject matter experts in the case to which students are assigned. Students have access to other faculty, who serve as expert resource persons outside of the group. In the Dentistry and Mathematics courses, faculty serve as expert resource persons within the groups.

\section{Lessons Learned}

1. The six elements identified in the literature provide a prescription for using collaborative learning techniques. In spite of the great variation in the approaches reported here, each provided the six elements outlined earlier in this paper: positive interdependence, high degree of verbal, face-to-face interaction, individual accountability, social skills, group processing, appropriate grouping. Each of 
these elements provides a "building block" for a cooperative learning approach and should be addressed in course design.

2. A clear structure should be imposed. A structure provides a set of guidelines for students (and faculty) in the overall course organization, small group process, and assessment methods. As described in this paper, structures can vary widely, but should be communicated to students and faculty in advance, and adhered to during the course. There is a voluminous body of literature which describes the various models and structures which can be utilized in a cooperative learning approach.

3. Cooperative learning is highly beneficial to students. The literature has clearly established the benefits to students. These benefits were observed in all three approaches reported here, and students' ratings and comments were generally positive. Students learn quickly to assume more responsibility for their learning, and faculty become more familiar with the strengths and weaknesses of their students through observation. Therefore, students who are in difficulty can be identified early, and appropriate remediation can be provided.

4. Students respond very positively to cooperative learning. As reported by students in all three approaches described in this paper, most students are very positive about this approach. They reported that this approach enhances their learning, problem-solving, critical thinking, communication skills and motivation. It appears that cooperative learning "empowers" students, and that most students are willing to assume the additional responsibility for the effective functioning of their group.

5. Preparation of faculty is essential. Most faculty members have developed their teaching skills through many years of lecturing. Although there are notable exceptions, most faculty still define their role as "transmitters of information." As shown in Table 3, there are multiple faculty roles in cooperative learning, such as "facilitator" and "manager" of the learning process. Faculty need to be prepared and supported during this role transition, which requires additional skills not previously learned.

6. Preparation and support of students is critical. University students are generally offered a traditional lecture-based approach, and have not been required to work cooperatively, nor to be self-directed 
learners. Cooperative learning requires more effort from them, and some discomfort with the process is expected during the transition period. It is critical to provide students with a rationale for this approach, guidance in how to use it successfully, and support when difficulties are encountered.

7. Cooperative learning is more resource-intensive. A lecture-based course requires a minimum of one faculty member and one classroom. The course is based on the faculty member's lecture notes and the assigned readings. Although cooperative learning structures can be implemented with a large group in a lecture-theatre, this approach is rather limited. To fully realize the benefits of cooperative learning requires small groups, prepared cases, appropriate classrooms, and a dedicated team of faculty. Although the benefits to students have been well established, it is not always clear to faculty that the amount of learning is commensurate with the time spent in preparing and carrying out cooperative learning activities.

8. A minority of students may be uncomfortable with this approach. In a lecture-based course, students have the option of not attending (and later obtaining the lecture notes from a peer); in small-group cooperative learning regular attendance is important for effective group functioning. Therefore, additional responsibility is placed on students in this setting. Although the feedback from students in all three approaches is positive, it is not unanimous. There is a small proportion of students who are uncomfortable with the process. This may be due to several factors, such as previous experience, personality or learning style. Some mechanism should be provided to assist these students, and to provide the additional support which may be required.

9. Implementing cooperative learning with students increases cooperation among faculty. In all three approaches, faculty were required to work cooperatively in order to design and implement the cooperative learning approach. This is exceptional in the university environment, where faculty tend to work independently. Cooperative learning has the potential to bring together faculty from disparate disciplines, and with different teaching philosophies, and to unite them in a common purpose. 
This paper describes three widely divergent approaches to cooperative learning. The approaches involved students at different educational levels, and in different disciplines, who were using different cooperative learning processes and structures. Nonetheless, analysis of the three approaches showed an underlying similarity - each had incorporated the six essential elements described in the literature for implementing cooperative learning. Feedback from students and faculty generally was positive, and student comments mentioned benefits of cooperative learning which have been well documented in the literature, e.g., active learning and development of problem-solving and communication skills. It is clear that cooperative learning is a robust instructional approach, and by following the six essential elements, it can be customized to meet the needs of students and faculty across a variety of disciplines.

\section{References}

Astin, A.W. (1993). What matters in college: Four critical years revisited. San Francisco, CA: Jossey-Bass.

Barrows, H.S. (1988). The tutorial process. Springfield, IL: Southern Illinois University.

Barrows, H.S., \& Tamblyn, R.W. (1980). Problem-based learning. New York, NY: Springer Publishing.

Basili, P.A., \& Sanford, J.P. (1991). Conceptual change strategies and cooperative group work in chemistry. Journal of Research in Science Teaching, 28, 293-204.

Bassarear, T., \& Davidson, N. (1992). The use of small group learning situations in mathematics instruction as a tool to develop thinking. In N. Davidson \& T. Worsham (Eds.), Enhancing thinking through cooperative learning (pp. 235-250). New York, NY: Teachers College Press.

Bennett, N. (1991). Cooperative learning in classrooms: Processes and outcomes. Journal of Child Psychology and Psychiatry, 32, 581-594.

Bossert, S.T. (1988-89). Cooperative activities in the classroom. In E.Z. Rothkopf (Ed.), Review of Research in Education 15, (pp. 225-250). Washington, DC: American Educational Research Association.

Boyer, E. (1990). Scholarship reconsidered. Lawrenceville, NJ: Princeton University Press.

Chickering, A.W., \& Gamson, F. (Eds.). (1991). New directions for teaching and learning: No. 47. Applying the seven principles for good practice in undergraduate education. San Francisco, CA: Jossey-Bass. 
Cinelli, B., Symons, C.W., Bechtel, L., \& Rose-Colley, M. (1994). Applying cooperative learning in health education practice. Journal of School Health, $64,99-102$.

Cobb, K.B., \& Conwell, C.R. (Eds.). (1988). Science EQUALS success. Washington, DC: Office of Educational Research and Improvement. ERIC document ED324199.

Crowley, M., \& Dunn, K. (1994). Clue cards: A cooperative learning technique. Primus, IV, 125-131.

Cuseo, J. (1992). Collaborative and cooperative learning in higher education: A proposed taxonomy. Cooperative Learning and College Teaching, 2(2), $2-4$.

Dansereau, D.F. (1988). Cooperative learning strategies. In C.E. Weinstein, E.T. Goetz, \& P.A. Alexander (Eds.), Learning and study strategies: Issues in assessment, instruction and evaluation (pp. 103-120). New York, NY: Academic Press, Inc.

Davidson, N., \& Worsham, T. (Eds.) (1992). Enhancing thinking through cooperative learning. New York, NY: Teachers College Press.

George, P.G. (1994). The effectiveness of cooperative learning strategies in multi cultural university classrooms. Journal on Excellence in College Teaching, 5, 21-30.

Glendon, K., \& Ulrich, D. (1992). Using cooperative learning strategies. Nurse Educator, 17, 37-40.

Holmes, D.B., \& Kaufman, D.M. (1994). Tutoring in problem-based learning: A teacher development process. Medical Education, 28, 275-283.

Johnson, D.W., \& Johnson, R.T. (1984). Circles of learning. Alexandria, VA: Association for Supervision and Curriculum Development.

Johnson, D.W., \& Johnson, R.T. (1989). Cooperation and competition: Theory and research. Edina, $\mathrm{MN}$ : Interaction Book Company.

Johnson, D.W., Johnson, R.T., \& Smith, K.A. (1991a). Active learning: Cooperation in the college classroom. Edina, MN: Interaction Book Company.

Johnson, D.W., Johnson, R.T., \& Smith, K.A. (1991b). Cooperative learning: Increasing college faculty instructional productivity (ASHE-ERIC Higher Education Report No.4). Washington, DC: The George Washington School of Education and Human Development.

Johnson, D.W., Maruyama, G., Johnson, R., Nelson, D., \& Skon, L. (1981). Effects of cooperative, competitive, and individualistic goal structures on achievement: A meta-analysis. Psychological Bulletin, 89(1), 47-62.

Kagan, S. (1990). The structural approach to cooperative learning. Educational Leadership, Dec./89-Jan./90, 14. 
Kaufman, D.M. (1995). Preparing faculty as tutors in problem-based learning. In A.W. Wright \& Associates (Eds.), Teaching improvement practices: Successful strategies for higher education (pp. 101-125). Bolton, MA: Anker Publishing.

Kaufman, D.M., \& Mann, K.V. (1996a). Students' perceptions about their courses in PBL and conventional curricula. Academic Medicine, 7I(1), S52-S54.

Kaufman, D.M., \& Mann, K.V. (1996b, in press). A comparative study of students' attitudes in PBL and conventional curricula. Academic Medicine.

Mann, K.V., \& Kaufman, D.M. (1995a). A response to the ACME-TRI report: The Dalhousie problem-based learning curriculum. Medical Education, 29, $13-21$.

Mann, K.V., \& Kaufman, D.M. (1995b). Skills and attitudes in self-directed learning: The impact of a problem-based curriculum. In Proceedings of the 6th Ottawa Conference on Medical Education.

Millis, B.J. (1991). Fulfilling the promise of the "seven principles" through cooperative learning: An action agenda for the university classroom. Journal on Excellence in College Teaching, 2, 139-144.

Millis, B.J. (1995). Introducing faculty to cooperative learning. In W.A. Wright \& Associates (Eds.), Teaching improvement practices: Successful strategies for higher education. Bolton, MA: Anker Publishing.

Norman, G.R., \& Schmidt, H.G. (1992). The psychological basis of problembased learning: A review of the evidence. Academic Medicine, 67(9), $557-565$.

Schmidt, H.G. (1989). The rationale behind problem-based learning. In H.G. Schmidt, M. Lipkin, M.W. de Vries, \& J.M. Greep (Eds.), New directions for medical education: Problem-based learning and communityoriented medical education (pp. 105-111). New York, NY: Springer-Verlag.

Slavin, R.E. (1980). Cooperative learning. Review of Educational Research, $50(2), 315-342$.

Slavin, R.E. (1983). When does cooperative learning increase student achievement? Psychological Bulletin, 94(3), 429-445.

Slavin, R.E. (1990). Cooperative learning: Theory, research and practice. Boston, MA: Allyn and Bacon.

Slavin, R., Sharan, S., Kagan, S., Hertz-Lazarowitz, R., Webb, C., \& Schmuck, R. (Eds.). (1985). Learning to cooperate, cooperating to learn. New York, NY: Plenum Press.

Stevens, R.J., Madden, N.A., Slavin, R.E., \& Farnish, A.N. (1987). Cooperative integrated reading and composition: Two field experiments. Reading Research Quarterly, 23, 433-454. 
Terenzini, P.T., \& Pascarella, E.T. (1994). Living with myths - undergraduate education in America. Change, Jan./Feb., 28-32.

White, R., \& Conwell, C. (1988). The impact of Project EQUALS in-service: Testimony of participating teachers. Charlotte, NC: University of North Carolina. ERIC document ED302389. 